These percentages are obtained by dividing the flour yields as reported by the mills by the flour contents of their wheats as expressed in Column 7, and multiplying the quotients by Ioo. Their efficiency is really lower than that indicated by the figures, which were calculated on the basis of the yield of flour which is appreciably contaminated with offal. The mills are given credit for this offal as though it were flour. This low efficiency is indicated in another way by the figures in Column 7 which express on a percentage basis the flour content of the several offals, which in one case runs as high as 37 per cent. The flour content of the offal in the first group, 27.9 per cent, is the lowest of all, and even in this case the loss is a serious one. This offal constituted 23.I per cent of the wheat, according to the miller's own report. The flour in the offal, therefore, constituted 6.44 per cent of the wheat. The flour recovered by the miller was 76.5 per cent of the wheat. Out of every roo lbs. of wheat containing 82.9 lbs: of flour, this miller recovered $76.5 \mathrm{lbs}$, and allowed the remaining 6.44 lbs. to go into the feed. Assuming that this flour sold for $\$$ I 2 a barrel and his feed for $\$ 60$ a ton, he received $\$ 0.06$ a pound for the flour and $\$ 0.03$ a pound for the feed. The $6.44 \mathrm{lbs}$. which went into the feed brought him \$0.193, whereas it should have brought him $\$ 0.386$ if recovered as flour and sold as such. He lost, thereby, \$o.r93 for every I00 lbs. of wheat milled. In the case of a rooo-bb1. mill this loss would approximate $\$ 500$ a day. Where the offal contained 37 per cent of flour the loss in a mill of the same size would amount to $\$ 900$ a day. These figures bring out in an emphatic manner the prevailing low efficiency of modern flour mills. A knowledge of this condition should stimulate efforts among millers to make a more complete recovery of flour.

\section{SUMMARY}

I-The inner endosperm or true flour-producing portion of the wheat kernel contains all the starch and only very small percentages of pentosans and fats.

2-The bran tissue including the aleurone layer contains a high percentage of pentosans, 5 or 6 per cent of fat, and no starch. The pentosan content of the offal tissue is fairly constant.
3 - The embryo or germ and the aleurone layer contain a high percentage of fat, and no starch.

4-The amount of fat and pentosans in any grade of flour is a measure of the amount of offal (germ and bran) contained in that flour. The amount of starch contained in wheat or any mill product is a measure of the amount of inner endosperm and, therefore, of the amount of flour contained in that product.

5-The accuracy of the flour-yield determination of wheat as made by the ordinary experimental mill is dependent on two very important factors: the skill of the operator, and the completeness of the equipment. The methods outlined in this paper will not be subject to the errors inherent in a milling test and will constitute a more accurate means of estimating the exact flour content of any given wheat.

6 - The determinations of pentosans or starch may be used as a control of the miller's yield reports.

7 -These determinations and formulas may also be used for obtaining the milling efficiency on a percentage basis.

\section{WELDING THERMOCOUPLES IN THE ELECTRIC ARC By James C. McCullough \\ Severance Chemical, Laboratory, Oberlin College, Oberlin, O. Received May 27, 1920}

The oxyacetylene flame usually employed for welding thermocouples is not always available, and with other gases it is difficult to secure the necessary heat without oxidizing the wires.

Base-metal thermocouples are easily and quickly welded in the electric arc, providing oxidation is prevented. A generous stream of illuminating gas is directed against the electric arc, and the twisted ends of the thermocouple wires are brought into the arc and fused together. Cooling for a few seconds in the gas prevents any trace of oxidation and no flux is required. Fifteen amperes alternating current has usually been employed, but for the larger sizes of wire a higher amperage is needed. The direct current arc is more efficient. The eyes of the operator must be protected by colored glasses.

\title{
THE WATER SUPPLY OF THE AMERICAN EXPEDITIONARY FORCES'
}

\section{By Edward Bartow}

Formerly l,ieutenant Colonel, Sanitary Corps, U. S. A., In Charge of Water Analysis I aboratories, A. E. F.

In the United States during the World War the construction and maintenance of water supplies for the Army was the duty of the Construction Division of the Quartermaster Corps; in the American Expeditionary Forces it was the duty of the Water Supply Service of the Engineer Corps. A regiment of water supply engineers, the 26th Engineers, was provided in the tables of organization of the A. E. F. This regiment was organized in the United States early in 1917, two of the companies were sent to France late in 1917 , and the remainder in 1918 . The

1 Published by permission of the Surgeen General, U. S. Army.
Medical Department was to have control of the quality of water furnished, and detailed to each of the six companies of the 26th Engineers an officer of the Sanitary Corps and three men of the Medical Corps who should make water analyses under orders of the engineers. The Medical Department also detailed one Sanitary Corps officer to be sanitary inspector of water with each army division, under the orders of the chief sanitary officer of each division. Some of the officers of the Engineering and Medical Departments who were especially concerned with the quality of water felt that the division of authority indicated by 
these arrangements was unsatisfactory. To overcome the diffculty $^{1}$ the engineers were made responsible for the character of water delivered at the water points, and the Medical Department for any further treatment required. To carry out the requirements of the general orders, the Water Analysis Laboratories of the A. E. F. were established.

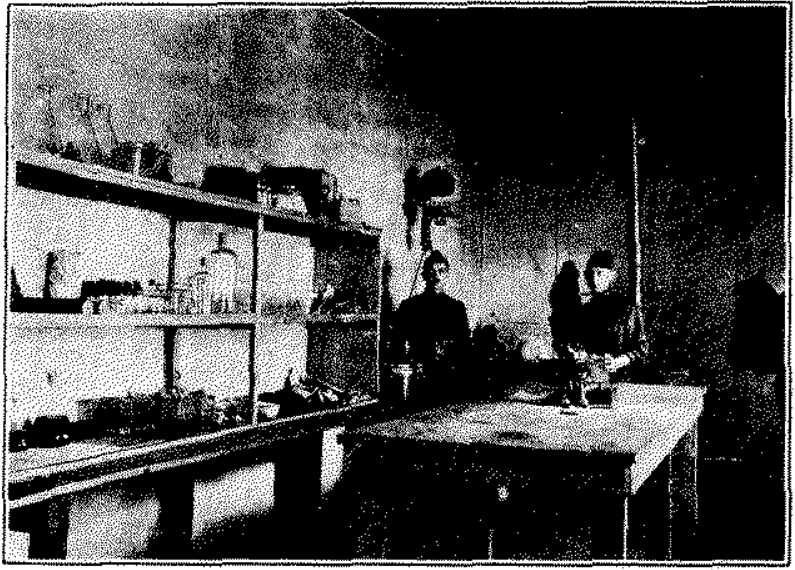

F5O, 1.MABORATORX AT LA MANS

In order to get the laboratories into operation as quickly as possible, officers and men qualified for laboratory and inspection work in water quality control were obtained as far as possible from troops in France, and requests were sent by cable through the office of the Chief Surgeon and General Headquarters for additional personnel.

\section{LOCATION AND FUNCTION OF LABORATORIES}

The personnel had direct charge from fixed laboratories over the quality of water in the Service of Supplies, including the base, intermediate, and advance sections, and from mobile laboratories accompanying the $26 \mathrm{th}$ Engineers, over the quality of water in the zone of the Army or fighting area. The personnel attached to the water analysis laboratories worked in coöperation with the division sanitary inspectors of water, who moved from place to place with their respective divisions.

Owing to the relation between the officer-in-charge of the water analysis laboratories and the French government, it was desirable that the central laboratory be located at Paris. The laboratories at Dijon and Tours were next in importance. At Dijon the laboratory was in the central laboratory of the Medical Department. At Tours it was near the office of the Water Supply Service of the Division of Construction and Forestry. Other laboratories were located at St. Nazaire (Base Section No. x), Bordeaux (Base Section No. 2), Winchester, England (Base Section No. 3), Le Havre (Base Section No. 4), Brest (Base Section No. 5), La Rochelle (Base Section No. 7), Nevers (Intermediate Section, East), Neufchateau (Arny Laboratory No. I), and Le Mans (American Embarkation Center).

Each laboratory had control of water supplies for troops on the transports at the base ports, and for troops who might be stationed in cities, camps, supply depots, or hospitals in that part of the country administered from the headquarters of the section in which they were located. It was expected that Army laboratory No. I and the mobile laboratories with the 26 th Engineers would make analyses of water furnished at the water points and also any analyses desired by the sanitary inspectors of water. The sanitary inspectors of water with the divisions, moving with the divisions, had as their especial duties the supervision of sterilization or disinfection of water furnished

General Orders 34 and 131, and Bulletin 65, General Headquaters, A. E. E. 1918. the troops, and it was not expected that they would have time to do analytical work.

\section{ANALXTICAL METHOD}

The methods of analysis of the American Public Health Association and the AMERICAN Chemical SocieTy, together with the bacteriological standard adopted for drinking water to be used on common carriers in interstate commerce, were taken as the basis of analysis and interpretation of results. A "Bulletin on Water Analysis Adapted for Use in the Water Analysis Laboratories of the A. E. F." was compiled and distributed. The bacteriological methods have been reported to the Society of American Bacteriologists. The sanitary chemical methods included tests for turbidity, color, odor, residue, alkalinity, chloride, nitrate nitrogen, nitrite nitrogen, oxygen consumed, and total hardness. Industrial water analysis included determinations of carbon dioxide, alkalinity, non-carbonate hardness, magnesium, chloride, sulfate, and iron. It was also necessary to make determinations of the quality of bleaching powder and to determine whether a treated water contained an excess of chlorine.

ACRIVITIES OF THE VARIOUS LABORATORXES

Active work was begun at the Paris laboratory in January 1918 , when the engineers sent samples to the laboratory with a request that analyses be made and an opinion given concerning their suitability for use in boilers, and concerning methods of treatment if the waters were not suitable.

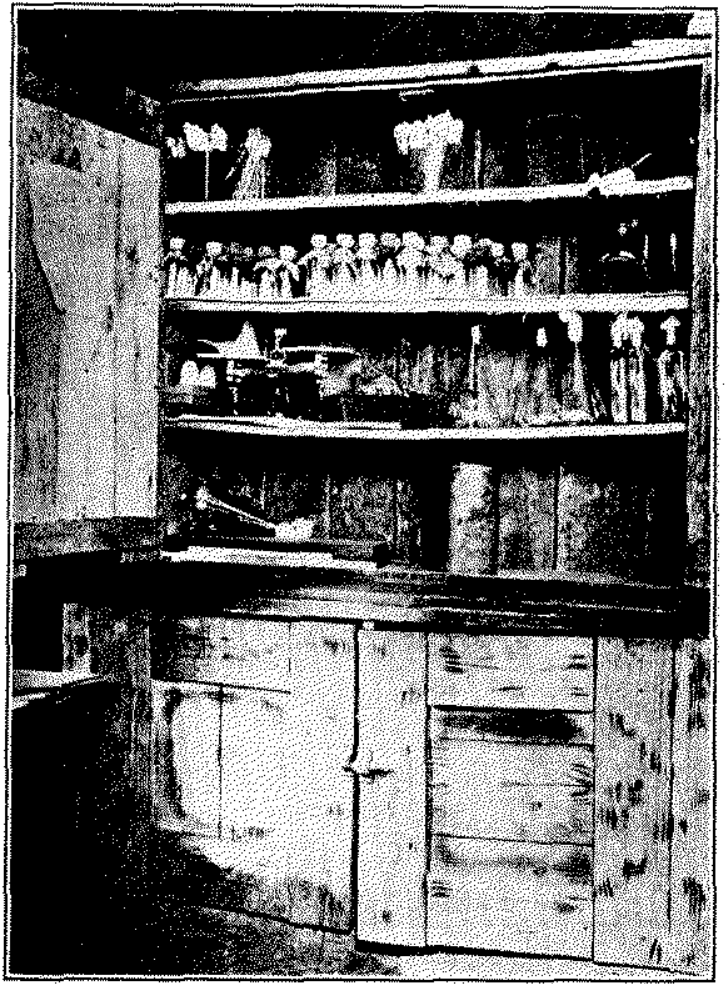

Fig, 2-I a BORATOKY EQURMENT AT NXVERS

ST. NAzArrem-About the same time representatives of the laboratories were sent to St. Nazaire to make a survey of the salinity of the Loire River. The water in St. Nazaire was in stuficient for the needs of the city and the Americant troops stationed there, and it became necessary to furnish an additional supply. A dan and reservoir were constructed, but after the completion of the dam there was no rain and the reservoir remained empty. Five hindred thousand gallons of water per day had to be carried by tank boat from a fresh water stream up the Loire River and pumped into the city mains. A dam was 


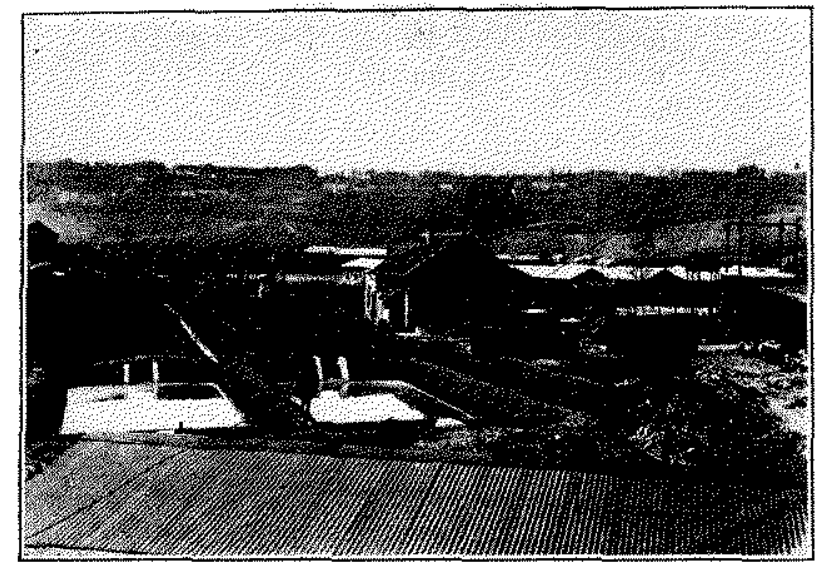

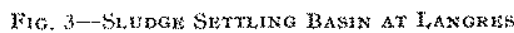

constructed on another river, the Brivet, to cut out the salt tide water and retain the fresh water. Before this dam was completed the water suppiy became so low that a portion of a fresh water transportation canal, the Trignac Canal, was cut of by a dam and used as a sedimentation basin. Alum was added as the water fiowed through a weir in the dam, liquid chlorine was adted to the coagulated and settled water, and it was then pumped to the St. Nazaire filter plant. The treatment was under the supervision of the St. Nazaire laboratory. The filter plant used by the French at St. Nazaire was of the slow sand type and barely adequate for the needs of the city. The Americans constructed a rapid mechanical fllter of about $2,500,000-\mathrm{gal}$. capacity, and installed a liquid chlorine tnachine to sterilize the effluent. An additional filter plant was also constructed to supply water to the camp at Montoir, where freight from St. Nazaire was stored. The laboratory supervised both filter plants. Representatives from this laboratory visited regularly the hospitals and camps in Base Section No. I, including artillery camps and four aviation camps.

BORDEAUX-At Bordeaux sufficient water was not available for the docks and the adjoining camps. After a study of geological conditions deep wells were drilled which at a depth of $800 \mathrm{ft}$. struck an excellent flow of splendid water. Mach of three wells furnished 500,000 gal. a day. Daily analytical control of this supply was not necessary, but the laboratory had charge of several sterilizing machines which were connected with the stupplies for Mt. Desert Hospital, the storage camp at St. Sulpice, where the freight landed at Bordeaux was stored, and at many other cities and camps in the base section, including several lumber camps. Representatives from this office also inspected water supplies in the leave area in southwestern France.

BREST - When Brest was chosen for a port of entry for American troops there was a supply of water sufficient only for the inhabitants of the city and for the French naval station located there. The water was obtained from gathering. galleries located in the neighboring hills and flowed by gravity to the city and to the naval station. The barracks at Pontanesan were served by water from a spring which because of its doubtful quality had been filtered through trickling filters. With the influx of American troops none of these supplies were adequate, nor was there sufficient water to supply the transports, some of which could not carry enough for the round trip from the United States. A contract was made with the French naval authorities to allow water from as mall stream, Penfeld River, to pass into their mains to increase the supply, and an extension was made from the mains to the docks. Permission was given to use the water from the stream, provided it should be made of as good bacteriological quality as the water already in use, and also that it should have no taste and odor. In order to make the water available, a reservoir formerly used as a mill pond was enlarged and cleaned out by the American troops. Three hundred pounds of calcium hypochlorite were spread over the bottom, and water allowed to enter from the stream, forming a fairly concentrated solution. After this solution had remained in the pond for several hours it was replaced with fresh water from the strean. Iiquid chlorine added to the effluent from the pond at the pumping station sterilized it.

Comparative tests made by the chemists and bacteriologists at the French naval station and by representatives of the Water Analysis Laboratories showed that the sterilization was satisfactory and that there was no taste or odor from an excess of chlorine, and the water was allowed to enter the mains. It later became necessary to build an additional reservoir of concrete and to construct an independent line to the Pontanesan barracks and the American pier. With the increased facilities, tank boats of 8oo-tons capacity could be quickly filled and the water transferred rapidly to the transports in the harbor.

On June 22, 1918, soon after the water from Penfeld River was put in use, a heavy rain following the most prolonged dry season in many yeats raised the water in the river. An intense amber color and a disagreeable taste developed. The alkalinity increased from 13 to no. The chloride content which would naturally fall as the water rose showed a very small fluctuation, changing from 34 to 39 . The bacteriological results were unsatisfactory, and use of the water was discontinued. Orders had been given to the officer-in-charge that if anything happened he should find the difficulty before the French laboratory discovered it, and the water had been shut off several hours before word came from the French laboratory that the water was unsatisfactory. The condition indicated special contamination, accompanying the increase in the quantity of water flowing into the river, The drainage area was carefully inspected and the

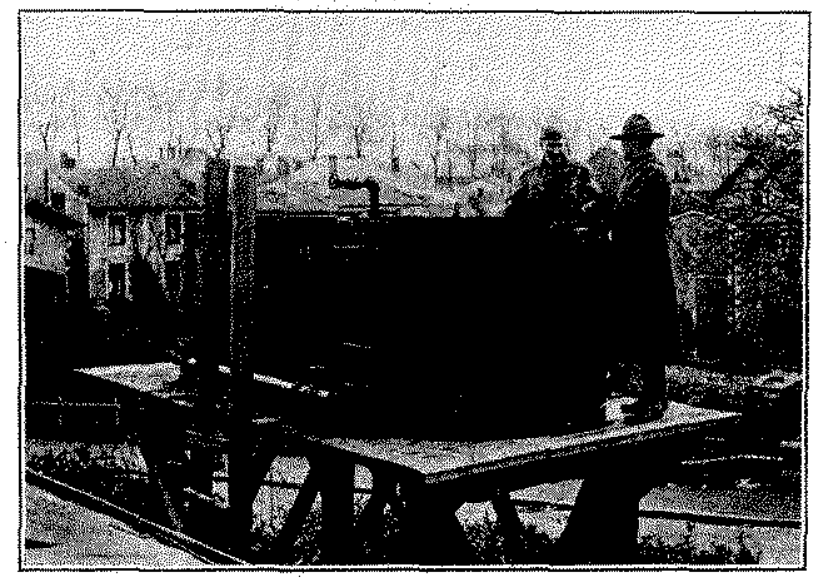

Frg. 4-Water Supplizs ror Troops in Transtr at Salnte. STERTLZZATION WITH JAVELLB WATER

trouble located in a branch of the stream, which had its source near a French aviation station where hydrogen for dirigible balloons was being made by the action of ferrosilicon on caustic. soda. Arrangements were at once made with the French authorities to retain this waste matter in concrete basins, one of which was already completed in connection with a proposed plan for the recovery of soda from the waste product. From the con crete basins the waste would be used in soda recovery or hatuled to the sea at a distance of about 8 kilometers.

To prevent future trouble, as it was absolutely necessary to supply water for the allied shipping in the harbor, arrange. ments were made and material secured to treat the water in the upper part of the dranage area with alum to clarify and de- 
colorize it, and to treat it farther down with sulfuric acid to neutralize the alkali. It was never necessary, however, to use these latter measures. The sterilization of the water with liquid chlorine was under the daily control of the laboratory, and it was of satisfactory quality for the transports and also for the camps at Pontanesan, which at times held as many as 80,000 men. The laboratory at Brest also had control of camps and hospitals in the base section.

LA ROCHEILE-La Rochelle obtained its water supply from gathering galleries dug in the low ground near the bay. The galleries were well protected by stone arches and under ordinary conditions the water was of good quality bacteriologically and of fair quality chemically. The mineral content was high, and during a dry season, because of the extra demand for water by the American troops, salt water from the bay seeped back, making the water so hard and salty that it could hardly be used for drinking purposes. The Americans made some improvement by sinking wells and digging additional ditches. It was necessary to use this hard water for bollers of locomotives and

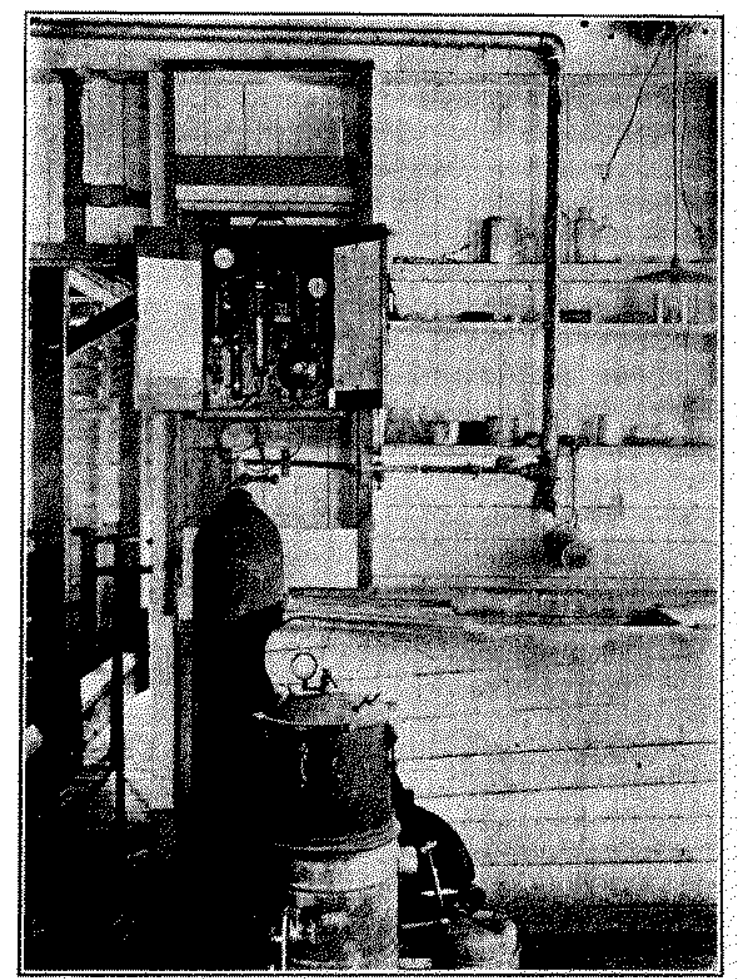

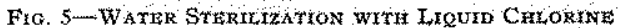

unloading cranes. The representatives of the Water Analysis Laboratories located at $\mathrm{La}$ Rochelle softened the water to be used in boilers, and recommendations were made for a watersoftening plant. The softening of the water greatly increased the efficiency of the locomotives and cranes. This laboratory had quality control of several camps and hospitals in the neigh. borhood and was responsible for the use of javelle water, which is described later in this article.

In order to take care of the sick and wounded several hospital centers were established in various parts of the A. E. F. These centers were planned to contain 20,000 beds, and in case of an emergency to handle an expansion to 40,000 . The engineers constructed water systems for these units, and the purification and quality of the water was under the control of the Water Analysis Laboratories.

At Savenay, near St. Nazaire, a concrete dam $50 \mathrm{ft}$. high and $400 \mathrm{ft}$. across formed a reservoir of $140,000,000$-gal. capacity. This water flowed by gravity to a filter plant where, after sterilization, it was pumped to an elevated tank and to the hospitals.
At Mars the water was obtained from a river which varied so in height that it was necessary to construct a deep pumping pit, heavily weighted to prevent floating, and with a watertight wall several feet high above the surface to prevent flooding at times of high water. This construction is similar to that used on the Ohio and other American rivers which have a wide variation between high and low water.

At Beaune, Alleray, Langres, Mesves, and Bazoilles, installations more or less complicated were constructed by the American engineers. The quality of the water was under the control of the Laboratories.

\section{WATER FOR TROOPS IN TRANSIT}

Difficulty was experienced in obtaning sufficient water for troops in transit. The Railway Transportation Service, the Medical Department, the Engineer Department, and the Water Analysis Laboratories cooperated in an attempt to furnish water for filling canteens rapidly. At times of heavy troop movement, trains containing 1000 or more men would pass rapidly through the stations, giving but little time for the filling of canteens. Available water at the stations through which troop trains would pass was examined by the laboratories, and when it was found to be of good quality, a large number of faucets were installed by the engineers. When water was of doubtful quality, one or more tanks were erected, and a solution of bleaching powder added to the water in the tank. These tanks were connected with a suitable number of faucets in order that the troops might fill canteens promptly during their stay at the station. Pending the installation of tanks an attempt was made in several places to use lyster bags. These, however, were found unsatisfactory during rapid troop movements. They could not be filled quickly. It was necessary that the water should stand zo min. after treatment, and trains would often pass at less than 30-min. intervals. For stations where the troops movements were small, lyster bags were fairly satisfactory.

\section{WATER SUPPLY IN ARMY ZONE}

In the army zone, water points were constructed by the engineers. Wherever possible wells were used, but in that part of the front line occupied by the Americans it was difficult to obtain sufficient water from wells. Filter plants were constructed to use water from streams. When entering an area where there was insufficient water or during an advance; the so-called sterilab was used. This consisted of a pump, filter, and sterilizing apparatus mounted on a trick. It could be sent forward with troops and as more permanent installations were installed would be relieved for service elsewhere. When clear water was available a combination of pump and sterilizing apparatus was sufficient. Stationary filter plants were often constructed and operated within the range of the enemy's shell fire. The drinking water was sterilized by liquid chlorine machines, by solutions of bleaching powder, or javelle water. More than 150 liquid chlorine machines were in use by the A. E. F., and were located from the base ports to the Rhine. Solutions of bleaching powder were used on a large scale at some places, but it was used most often in lyster bags. Tubes containing about one gram of calcium hypochlorite were added to 36 gal. of water in the lyster bag. The British used bulk calcium hypochlorite, after determining the amount to use by a test devised by Col. Horrocks. By the Horrocks test the amount of bleaching powder needed to furnish an excess of chlorine was determined, and the taste and odor due to a large excess were avoided. Attempts made by some of the American officers to determine the amounts necessary did not prove satisfactory, owing to variation in the amount of bleaching powder in the tubes. Javelle water was used to a large extent by the French. Automatic machines for the delivery of solutions in proportion to the amount of water pumped have been devised by Vila and Buena Varilla. The Americans used all of these methods, but sterilization in the 
lyster bag holding 36 gal. of water was especially characteristic of the American army.

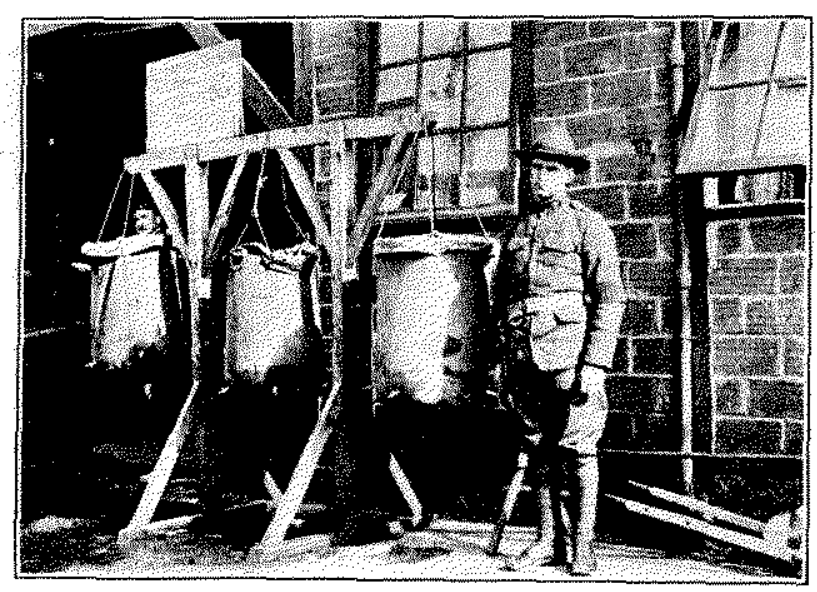

Fig. 6-LYSTER BAGS AT RAILWAX STATION

A gram of calcium hypochlorite added to $36 \mathrm{gal}$. of water in the lyster bag was equivalent to treating the water with two parts per million of available chlorine. In the spring of 1918 it was noticed that there was a high percentage of defective tubes in the calcium hypochlorite furnshed for use in the A. E. F. The laboratories at Bordeaux, Dijon, St. Nazaire, and Paris participated in studies of the quality and the physical condition of these tubes. The most extensive work was done at the Bordeaux laboratory. Some determinations of the actual weight of calcium hypochlorite and percentage of available chlorine were made, but, since a tube containing 0.3 of a gram of available chlorine was really desired, the percentage of chlorine in the salt was immaterial, provided the proper amount was present. Therefore, most of the analyses were made by titration of the contents of the tube without weighing it. By inspection alone, broken tubes, fauttily sealed tubes, and tubes containing insufficient calcium hypochlorite could be discarded. If the tube was whole and the contents dryt the thaterial would fall from one end of the tube to the other as a powder.
The contents of such tubes were usually found to be of good quality. As illustrating the success of this method, from 720 tubes, 37 were picked out as stupposedly defective. The available chlorine was deternined in each of these, with the result that soo per cent were found to have less than 0.2 g. of avaliable chlorine. Fifty-three of the remaining supposedly good tubes were selected at random for analysis. Nine per cent of these tubes had less than $0.2 \mathrm{~g}$, and $9 \mathrm{I} .5$ per cent had more than $0.25 \mathrm{~g}$. of available chlorine. Beginuing in the summer of 1918 all tubes coming into Base Section No. 2 by way of Bordeaux were inspected. Six and onewalf per cent of the tubes of one lot were found defective, and 41 per cent of tubes from another manufacturer were found defective. As a restult of this work stggestions were made through military channels that inspectors be placed in all factories manufacturing these tubes in order to eliminate to a certain extent the large number of broken and defective tubes received in France.

The Water Analysis Laboratories were called upon to analyze samples of alum offered to the engineering department for use in water treatment. Analysis was made according to the methods of the American Public Health Association and the AMERICAN CHEMTCAL SOCHETY.

At the request of the air service, analyses of the mineral content of water from established aviation stations and from proposed sites for aviation stations throughout France were made. It was the purpose of the air service to soften the water with permutit for use in the radiators of water-cooled motors. Several equipments for water soltening were installed in consultation with laboratories. The laboratories also had control of water treatment for several aviation stations.

At the request of the Quartermaster Departinent, water used at the laundry at $S t$. Plerre du Corps was examined and recommendations made that a permutit water-softening plant be installed. The installation of this plant reduced the quantity of soap and sodium carbonate recuired, the washing was more easily done, and the washed materials, especially woolen goods, were in much better condition than when hard water was used.

As a restit of examination of water at I a Rochelle a lime-soda softening plant was recommended. This, however, was never constructed. Soda and a French boiler compound were used to treat the water added to the boilers.

\section{IMPRESSIONS OF THE ITALIAN CHEMICAL INDUSTRY}

Editor of the Journal of the Industrial and Engineering Chemistry:

Before leaving America I promised you to try to write a letter from each country in turn, regarding my impressions of the chemical industries therein. I have been so extremely busy that, althongh my experiences in England, France, and Belgium gave me some knowledge of the developments in each, I have been unable to put anything on paper... Now a day is at my disposal for rest here in this charming spot, and I have had such a wonderful reception as America's representative at the meeting here in Italy that part of it shall be spent in fulfiling my promise, so far as Italy is concerned. I am doubly urged to do so for the June issue of the Journal which you kindly sent is before me, with Mr. Hopkins' interesting article. While the statistical data upon which he bases his conclusions have led him to concede decided development to Italy's chemical industries, his conciusions fall far short of the reality, as you will note in what follows.

The second meeting of the International Union of Pure and Applied Chemistry, which brought me to Italy, was a grand success. Prof. Lormand, your French correspondent, has already, or will shortly send you a full account of it as a part of his July letter. I wish sinply to add that the social furctions were charmingly carried out, and were accompanied by an artistic coloring and delightful touch which $\mathrm{I}$ doubt if one ever finds quite so delicate as in this truly charming and "simpatica" country. The ladies for example will always remember the lovely individual botiquets that each found beside her plate at the banquet, nor will the memory be less lasting from the fact that each was tied not only with the colors of Italy but with the colors of the home country of the recipient.

Following and during the meeting, we were taken to see something of Italy's chernical development, and this is where you are specially interested. We were received with charming and openhanded hospitality, but best of all we were actually shown the plants and their details, not simply walked through them as is so often the case in America. The Italian was justly proud of the work of his chemists and engineers, and was anxious that his guests too see something of their actual accomplishments. There was no secrecy so far as we were concerned; they described their methods and their apparatus; and seemed to invite inquiries where anything was obscure. If I can judge from the treatment I received, one would believe that Italy's industries 